Fixed Point Theory, 23(2022), No. 1, 239-246

DOI: $10.24193 /$ fpt-ro.2022.1.15

http://www.math.ubbcluj.ro/ ${ }_{\text {nodeacj/sfptcj.html }}$

\title{
A FIXED POINT DICHOTOMY
}

\author{
J. FERRER* AND E. LLORENS-FUSTER** \\ *Departamento de Anàlisis Matemàtico, Universidad de València, \\ Dr. Moliner, 50, 46100 Burjassot, València, Spain \\ E-mail: jesus.ferrer@uv.es \\ ** Departamento de Anàlisis Matemàtico, Universidad de València, \\ Dr. Moliner, 50, 46100 Burjassot, València, Spain \\ E-mail: enrique.llorens@uv.es
}

\begin{abstract}
We give here a dichotomic fixed point result for a certain class of mappings defined in the closed unit ball of a Hilbert space. This dichotomy states that, for any of the mappings in this class, either it has a fixed point or its Lipschitz constant with respect to any renorming of $\ell_{2}$ has to be strictly greater than 1 .
\end{abstract}

Key Words and Phrases: Fixed point, nonexpansive mapping, classical fixed point free mappings. 2020 Mathematics Subject Classification: 47H10, 54H25.

\section{REFERENCES}

[1] J.B. Baillon, Quelques aspects de la théorie des points fixed dans les espaces de Banach, I, Séminaire d'Analyse Fonctionelle de l'École Polytechnique, 7(1978-79), 1-13.

[2] J. Ferrer, E. Llorens-Fuster, On a class of maps which cannot be made nonexpansive after renormings, J. Nonlinear Convex Anal., 18(2)(2017), 197-214.

[3] J. Ferrer, E. Llorens-Fuster, Lower bounds for the Lipschitz constants of some classical fixed point free maps, J. Math. Anal. Appl., 465(2018), no. 1, 297-308.

[4] J. Ferrer, E. Llorens-Fuster, On never nonexpansive mappings in reflexive Banch spaces, Banach J. Math. Anal., 14(2020), no. 1, 76-97.

[5] J. Ferrer, E. Llorens-Fuster, A short proof that some mappings of the unit ball of $\ell_{2}$ are never nonexpansive, Amer. Math. Monthly, 127(2020), no. 4, 354-358.

[6] K. Goebel, W.A. Kirk, Classical theory of nonexpansive mappings, Handbook of Metric Fixed Point Theory, 49-91, Kluwer Acad. Publ., Dordrecht, 2001.

[7] K. Goebel, W.A. Kirk, Some problems in metric fixed point theory, J. Fixed Point Theory Appl., 4(2008), no. 1, 13-25.

[8] K. Goebel, W.A. Kirk, R.I. Thele, Uniformly Lipschitzian semigroups in Hilbert spaces, Canad. J. Math., 26(1974), 1245-1256.

[9] K. Goebel, S. Reich, Uniform Convexity, Hyperbolic Geometry and Nonexpansive Mappings, Marcel Dekker, New York and Basel, 1984.

[10] S. Kakutani, Topological properties of the unit sphere of a Hilbert space, Proc. Imp. Acad. Tokyo, 19(1943), 269-271.

The first author has been supported by grant MTM2017-83262-C2-1-P. 
[11] S. Reich, The fixed point property for nonexpansive mappings, I, Amer. Math. Monthly, 83(1976), 266-268.

[12] S. Reich, The fixed point property for nonexpansive mappings, II, Amer. Math. Monthly, 87(1980), 292-294.

[13] D.R. Smart, Fixed Point Theorems, Cambridge University Press, 1974.

Received: September 6, 2020; Accepted: June 14, 2021. 
FIXED POINT DICHOTOMY 